\title{
Elderberry and Elderflower (Sambucus spp): Markets, Establishment Costs, and Potential Returns ${ }^{1}$
}

\author{
Kevin Athearn, David Jarnagin, Ali Sarkhosh, Juanita Popenoe, and Steven Sargent ${ }^{2}$
}

\section{Introduction}

This publication is part of a series on elderberry production in Florida. Other publications in the series cover cultivation practices and phytochemical research. The focus of this document is on markets, establishment costs, and potential returns for commercial elderberry production in Florida. Cost and return estimates are based on a 3-acre elderberry orchard following organic standards. The information is intended to assist farmers in evaluating elderberry as a possible alternative crop and to aid in financial planning for an elderberry enterprise.

Wild and cultivated varieties of the elderberry plant grow in many parts of the world. The American elderberry, Sambucus nigra ssp. canadensis, is native to eastern North America (Charlebois et al. 2010). The native Florida type was formerly separated as its own species $S$. simpsonii and exhibits substantial differences from commonly cultivated varieties of S. nigra ssp. canadensis and European S. nigra. Varietal differences can include growth habit, fruiting habit, harvest time, disease resistance, fruit and flower quality, and other factors affecting crop management and commercial potential (Jarnagin et al. 2020). Prospective growers are encouraged to seek advice from specialists or experienced growers in Florida regarding varietal selection.
Elderberry products have established commercial value, but Florida production is currently limited to a small, cottage industry. Elderberry is an alternative crop that holds promise for further commercial development in Florida. This publication reviews information on markets for elderberries and elderflowers (Figure 1) and estimates establishment costs and potential returns for a 3-acre elderberry orchard managed organically in Florida. Information about cultural practices can be found in another publication, Elderberry and Elderflower (Sambucus spp): A Cultivation Guide for Florida.

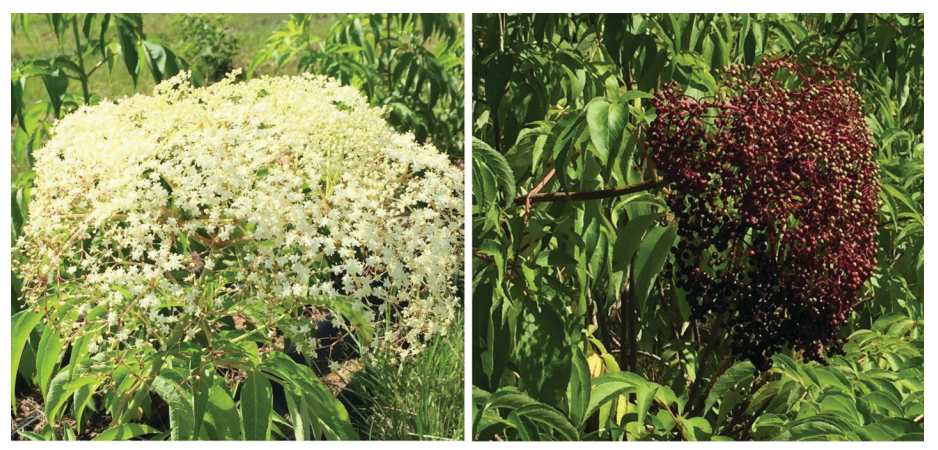

Figure 1. Elderflower and elderberry cymes.

Credits: Hyldemoer + Co., Florida

\section{Market Potential}

The elderberry plant can provide numerous marketable products. Berries and flowers are the two primary products sold, but leaves, bark, roots, wood, and cuttings from

1. This document is FE1093, one of a series of the Food and Resource Economics Department, UF/IFAS Extension. Original publication date March 2021. Visit the EDIS website at https://edis.ifas.ufl.edu for the currently supported version of this publication.

2. Kevin Athearn, UF/IFAS Extension regional specialized agent, UF/IFAS North Florida Research and Education Center, Suwannee Valley; David Jarnagin, Hyldemoer + Co.; Ali Sarkhosh, assistant professor and Extension specialist, Horticultural Sciences Department; Juanita Popenoe, UF/IFAS Extension multi-county commercial fruit production agent, UF/IFAS Extension Lake County; Steven Sargent, professor and Extension postharvest specialist, Horticultural Sciences Department; UF/IFAS Extension, Gainesville, FL 32611.

The Institute of Food and Agricultural Sciences (IFAS) is an Equal Opportunity Institution authorized to provide research, educational information and other services

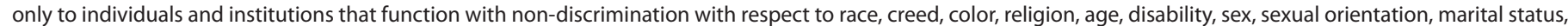

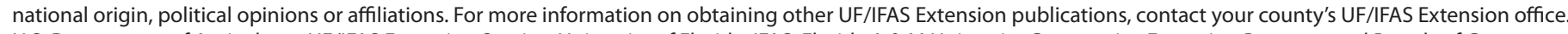
U.S. Department of Agriculture, UF/IFAS Extension Service, University of Florida, IFAS, Florida A \& M University Cooperative Extension Program, and Boards of County Commissioners Cooperating. Nick T. Place, dean for UF/IFAS Extension. 
American elderberry may have market potential as well (Charlebois et al. 2010; Byers et al. 2014). The remainder of this section will focus on markets for elderberries and elderflowers.

Elderberries and elderflowers are sold primarily as ingredients for food and beverage products and dietary supplements. Final products made with elderberry and elderflower include non-alcoholic beverages, such as tea, juice, syrups, and cordials, in addition to a range of alcoholic beverages including wine, gin, liqueurs, beers, ales, and ciders. Food products made with elderberry and elderflower include jellies, jams, pies, and other baked goods. As a dietary supplement or cold and flu remedy, elderberry is sold as a liquid or reconstituted extract, or as an ingredient in capsules, gummies, or lozenges. Elderberries can also be used as a natural food colorant and as dye for textiles.

Some sources recommend against eating raw elderberries, or other parts of the plant, because of possible toxicity (CDC 1984; Stevens 2001). These sources recommend cooking the berries, but a recent study detected only very low levels of cyanogenic glycosides in fresh, ripe elderberries, posing no threat to consumers (Thomas 2019). Leaves, stems, and green berries should be avoided in juice preparation (CDC 1984; Thomas 2019).

Elderberries are rich in anthocyanins and phenolic compounds with strong antioxidant properties. Elderberry extracts have demonstrated a range of healthful benefits, including reduced duration and severity of flu symptoms (Zakay-Rones et al. 2004; Roschek et al. 2009; Ozgen et al. 2010; Mudge et al. 2016).

Frozen or dried berries can be sold directly to households. A 2009 study of US elderberry producers reported fresh or frozen elderberries selling at farmers markets or online for prices ranging from $\$ 3.00$ per pound to $\$ 5.00$ per pound (Cernusca et al. 2011). A current review of online prices found dried elderberry selling for between $\$ 20$ and $\$ 31$ per pound and dried elderflowers selling for between $\$ 4.10$ and $\$ 4.40$ per ounce. Elderberry kits containing dried elderberry and other ingredients are also sold to households.

Other markets for dried or frozen elderberry could include manufacturers of dietary supplements and food and beverage products, as well as wineries, breweries, distilleries, restaurants, and retailers. Market research estimates sales of elderberry as a food or supplement ingredient totaling \$113 million in the United States in 2019 (Grebow and Krawiec 2020).
Elderberry ranked $10^{\text {th }}$ among functional ingredients in the natural food group and $14^{\text {th }}$ in the specialty gourmet group in 2019. Elderberry sales grew $83 \%$ between 2018 and 2019 driven by products in the immune health and cold and flu remedy categories. Demand for elderberry is increasing as a functional immune support ingredient in beverages, including tea and pre-/probiotic beverage markets (Grebow and Krawiec 2020).

Many of the elderberry products on the market today use Sambucus nigra sourced from Europe. In the United States, 790 acres of commercial elderberry production were reported in 2017. Missouri accounted for nearly half the US acreage (369 acres) in 2017 (USDA-NASS).

A study of US elderberry growers found that much of the elderberry crop is frozen. Elderberry prices for sales to wineries ranged from $\$ 0.50$ per pound with stems on to $\$ 5.00$ per pound de-stemmed. The study reported berries selling for $\$ 11$ per pound to nutraceutical manufacturers (Cernusca et al. 2011).

Because of concerns about toxicity of fresh berries and how rapidly the berries and flowers can deteriorate without freezing, drying, or other processing, there is little market for fresh products. A commercial elderberry grower must have the ability to quickly process elder plant products onfarm, arrange for processing at an off-farm facility, or sell to a buyer or processor immediately after harvest. Markets and processing facilities for elderberries and elderflowers are not well established in Florida. Developing market channels and processing infrastructure will be important for the growth of a commercial elderberry industry in Florida.

\section{Establishment Costs and Potential Returns}

Costs will vary depending on a grower's specific practices, equipment, and management decisions. Yields will depend on the specific varieties grown, management practices, and growing conditions. Markets and prices are uncertain. Growers who can achieve high yields relative to costs and who can access high-value markets are most likely to be successful.

Based on a review of literature (Byers et al. 2014; Wilson et al. 2016; Kaiser and Ernst 2018) and recent trials on a Florida farm, we prepared a sample budget estimating establishment costs and potential returns for a 3-acre elderberry orchard. Because every grower's actual costs and returns will be different, prospective growers should make their own estimates that fit their unique situations. An 
elderberry budget template is available as an Excel file on the North Florida Enterprise Budget website (https://svaec. ifas.ufl.edu/extension-programs/agricultural-economics/ north-florida-enterprise-budgets/) to assist prospective growers with their own budget calculations.

Costs to establish an elderberry orchard include the initial investment in fixed assets (equipment and infrastructure); the first-year costs of the plant material, orchard preparation and planting; as well as ongoing orchard management costs (Figure 2). We assume labor is hired for orchard management, harvesting, and postharvest handling.

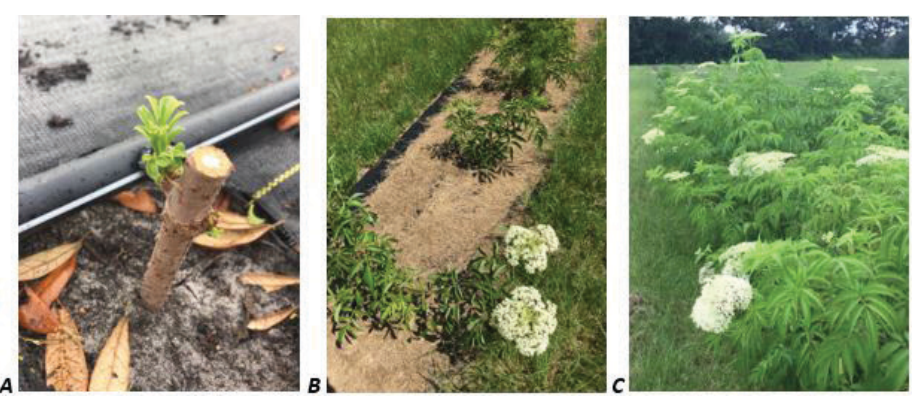

Figure 2. A: Elderberry hardwood cutting, B: Elderberry from cuttings at 4 months, $C$ : Elderberry from cuttings at 14 months in ground. Credits: Hyldemoer + Co., Florida

We provide a sample list of equipment and infrastructure, along with estimated costs, in Table 1 . We assume the orchard owner already owns three acres of land for the orchard, and that there is no opportunity cost (benefits forgone) from using the land for elderberry production. Suggested fixed assets needed for the orchard include a 4" well and pump with electric hookup, an equipment storage shed, a BCS (2-wheel) tractor, tractor implements, spray equipment and safety gear, hand tools, and an electric fence to deter deer. We assume the grower destems, washes, and freezes the elderberry on the farm. Fixed assets needed for harvest and postharvest handling include a packing and storage building, destemmer, wash sinks, freezer, harvesting containers, and miscellaneous processing equipment. The initial investment in these assets costs an estimated $\$ 65,800$. Annual depreciation is estimated at $\$ 3,960$. Adding interest, taxes, and insurance on these assets sums to a total annual fixed asset cost of $\$ 6,099$ per year ( $\$ 2,033$ per acre).

We estimate orchard establishment and operating costs for the first three years. Costs in Year 3 are assumed to be average annual costs for the remaining lifespan of the orchard (assumed to be 20 years). Table 2 shows estimated costs per acre. Year 1 establishment cost is estimated at $\$ 11,891$ per acre. Annual orchard management costs in the following years are about $\$ 6,000$ per acre. These costs include a \$14-per-hour charge for orchard labor.
Yields are expected to start low and increase to a plateau by Year 6 . Actual yields are uncertain, and the literature reports a wide range of yields. Yields of 6,000 pounds per acre or higher have been reported (Byers et al. 2014), but for this analysis we assume an average berry yield of 4,500 pounds per acre in Years 6 through 20. Yields and price assumptions are shown in Table 3. We assume 95\% of the berry yield is sold frozen wholesale, and 5\% is sold fresh or frozen directly to consumers. We assume up to 120 dozen elderflower cymes are sold fresh. Gross revenue reaches a plateau averaging \$15,135 per acre in Years 6 to 20 .

Harvesting labor, postharvest labor, and container or packaging costs will vary directly with yield amounts. We assume labor is hired to help with harvesting and postharvest activities, such as destemming, washing, packing, and freezing. After variable harvest and postharvest costs are subtracted, remaining revenue (on-tree revenue) is estimated at \$10,343 per acre in Years 6 to 20. These values are shown in Table 3.

The budget summary in Table 4 shows estimated annual revenues and costs for a mature elderberry orchard. It includes amortized costs from the first five years of the orchard prior to achieving a mature yield. Our estimate for annual gross margin per acre is $\$ 255$. This annual gross margin represents the return to selling-general-administrative (SGA) costs, land, and profit. SGA costs might include part of a pickup truck expense, accounting services, office supplies, business registration fees, marketing costs, food safety compliance costs, and organic certification, none of which are included in these budget estimates.

An investment analysis tracks cash costs and cash revenues over the 20-year lifespan of the orchard. Based on these budget estimates, our analysis shows a payback period of 17 years, an internal rate of return of $3 \%$, and a net present value slightly under break-even.

\section{Conclusion}

Although financial returns shown in the sample budget are relatively low, several factors affect the interpretation. Budgeted costs include hired labor at a rate of $\$ 14$ per hour (including payroll overhead). If the orchard owner or owner's family can manage without hiring labor, the $\$ 7,252$ labor cost per acre would be added to the net return (production margin). In that case, the production margin would represent the return to unpaid labor, SGA costs, land, and profit. 
The sample budget assumes the orchard must be established from scratch. If the orchard owner already has an irrigation well, buildings, fencing, or equipment, the upfront investment costs would be reduced.

The sample budget is based on management practices following organic standards, using weed barrier and OMRIlisted fertilizers, soil amendments, and pest management materials. Those practices increase costs. A grower must consider whether market price premiums or other benefits of organic management are worth the additional costs.

Yield estimates and market prices are key assumptions that critically affect profitability. Yields shown in the sample budget are moderate within the range of reported yields from other parts of the United States. Achievable yields for a mature elderberry orchard in Florida have not yet been documented. Demand for elderberry products appears to be growing, but effective marketing is essential to be able to obtain revenues above costs. Higher yields and higher prices, relative to costs, would increase profitability.

Labor is another critical factor affecting profitability. The amount of labor required for orchard management, harvesting, and postharvest handling is substantial and will vary from farm to farm. Orchard design, management practices, and the use of tools and machinery will affect the amount of labor required. Profitability depends partly on finding efficiencies and ways to reduce labor requirements and costs.

Risk is an inherent part of agriculture, and profit is not guaranteed. Growers must find competitive advantages in marketing or production and manage risk to maintain long-term profitability. Rising demand for elderberry products suggests good profit potential for growers who can obtain higher yields or higher value from processing and marketing, or who can find ways to lower costs without sacrificing yields.

Actual costs and returns will reflect an individual grower's unique situation, yields, and prices obtained. We recommend that new growers prepare their own budget estimates of expected costs and returns. The elderberry budget template, which can be downloaded from https://tinyurl. $\mathrm{com} / \mathrm{y} 9 \mathrm{v} 4 \mathrm{aw} 64$, can assist with preparing customized budget estimates.

\section{References}

Byers, P. L., A. L. Thomas, M. A. Gold, M. M. Cernusca, and L. D. Godsey. 2014. Growing and Marketing Elderberries in Missouri. Columbia, MO: University of Missouri.

Centers for Disease Control and Prevention (CDC). 1984. Poisoning from Elderberry Juice - California. Morbidity and Mortality Weekly Report. 33 (13): 173-4. Atlanta, GA. https://www.cdc.gov/mmwr/preview/mmwrhtml/00000311. htm.

Cernusca, M., M. Gold, L. Godsey. 2011. Elderberry Market Research. Columbia, MO: University of Missouri.

Charlebois, D., P. L. Byers, C. E. Finn, and A. L. Thomas. 2010. "Elderberry: Botany, Horticulture, Potential." Horticultural Reviews 37.

Grebow, J. and S. Krawiec. 2020. Ingredients to Watch: The 2020 List. Nutritional Outlook 23:1.

Jarnagin, D., A. Sarkhosh, J. Popenoe, S. Sargent, and K. Athearn. 2020. Elderberry and Elderflower (Sambucus spp.): A Cultivation Guide for Florida. HS1390. Gainesville: University of Florida Institute of Food and Agricultural Sciences. https://edis.ifas.ufl.edu/hs1390

Kaiser, C., and M. Ernst. 2018. Elderberry. Lexington, KY: University of Kentucky.

Mudge, E., W. L. Applequist, J. Finley, P. Lister, A. K. Townesmith, K. M. Walker, and P. N. Brown. 2016. "Variation of Select Flavonols and Chlorogenic Acid Content of Elderberry Collected throughout the Eastern United States." Journal of Food Composition and Analysis 47: 52-59.

Ozgen, M., J. Scheerens, R. Reese, and R. Miller. 2010. "Total Phenolic, Anthocyanin Contents and Antioxidant Capacity of Selected Elderberry (Sambucus canadensis L.) Accessions." Pharmacognosy Magazine 6 (23) : 198.

Roschek, B., Fink, R. C. Fink, M. D. McMichael, D. Li, and R.S. Alberte. 2009. "Elderberry Flavonoids Bind to and Prevent H1N1 Infection in Vitro." Phytochemistry 70:1255-1261.

Stevens, M. 2001. Plant Guide for Common Elderberry. Baton Rouge, LA: National Plant Data Center, USDA-NRCS. 
Thomas, A. L. 2019. Elderberry Flower Production and

Cyanide Concern. Mt. Vernon, MO: University of Missouri

Division of Plant Sciences Southwest Research Center.

https://www.greatplainsgrowersconference.org/up-

loads/2/9/1/4/29140369/elderberry_cyanide_st._joe_janu-

ary_2019.pdf

United States Department of Agriculture, National Agri-

cultural Statistics Service (USDA-NASS). 2017 Census of

Agriculture - State Data.

. Wilson, R., G. Nickerson, D. Fried, J. Hayden, G. Masé, T. Hardie, J. Faulkner, M. Sisock, T. L. Jackson, D. T. Handley, and M. L. Peronto. 2016. Growing Elderberries: A Production Manual and Enterprise Viability Guide for Vermont and the Northeast. Burlington, VT: University of Vermont.

Zakay-Rones, Z., E. Thom, T. Wollan, and J. Wadstein. 2004. "Randomized Study of the Efficacy and Safety of Oral Elderberry Extract in the Treatment of Influenza A and B Virus Infections." The Journal of International Medical Research 32:132-140. 
Table 1. Suggested investments in fixed assets for a 3-acre elderberry orchard.

\begin{tabular}{|c|c|c|c|c|}
\hline Orchard Equipment \& Infrastructure & Original Cost & $\begin{array}{l}\text { Use Life } \\
\text { (Years) }\end{array}$ & $\begin{array}{l}\text { Salvage } \\
\text { Value }\end{array}$ & Annual Depreciation \\
\hline Land, 3 acres & $\$ 0$ & 20 & $\$ 0$ & $\$ 0$ \\
\hline $4 "$ well \& 2 to $5 \mathrm{hp}$ pump, incl. electric hookup & $\$ 10,000$ & 20 & $\$ 0$ & $\$ 500$ \\
\hline Equipment storage shed & $\$ 3,000$ & 20 & $\$ 0$ & $\$ 150$ \\
\hline BCS tractor & $\$ 5,000$ & 10 & $\$ 0$ & $\$ 500$ \\
\hline Tractor implements/attachments & $\$ 4,000$ & 10 & $\$ 0$ & $\$ 400$ \\
\hline Deer-deterrent electric fencing & $\$ 2,000$ & 10 & $\$ 0$ & $\$ 200$ \\
\hline Spray equipment, including safety gear & $\$ 600$ & 5 & $\$ 0$ & $\$ 120$ \\
\hline Hand tools & $\$ 200$ & 5 & $\$ 0$ & $\$ 40$ \\
\hline \multicolumn{5}{|l|}{ Harvest \& Postharvest Equipment } \\
\hline Packing \& storage building & $\$ 20,000$ & 20 & $\$ 0$ & $\$ 1,000$ \\
\hline Destemmer & $\$ 8,000$ & 20 & $\$ 0$ & $\$ 400$ \\
\hline Wash sinks & $\$ 1,000$ & 20 & $\$ 0$ & $\$ 50$ \\
\hline Freezer & $\$ 10,000$ & 20 & $\$ 0$ & $\$ 500$ \\
\hline Containers \& misc. processing equipment & $\$ 2,000$ & 20 & $\$ 0$ & $\$ 100$ \\
\hline Totals & $\$ 65,800$ & & $\$ 0$ & $\$ 3,960$ \\
\hline
\end{tabular}

Table 2. Estimated annual operating costs for orchard management.

\begin{tabular}{|c|c|c|c|c|c|c|c|c|}
\hline \multirow[b]{2}{*}{ Materials } & \multirow[b]{2}{*}{ Unit } & \multirow[b]{2}{*}{$\begin{array}{l}\text { Cost per } \\
\text { Unit }\end{array}$} & \multicolumn{2}{|c|}{ Year 1} & \multicolumn{2}{|c|}{ Year 2} & \multicolumn{2}{|c|}{ Year 3 to 20} \\
\hline & & & Quantity & Cost & Quantity & Cost & Quantity & Cost \\
\hline Plants & each & $\$ 2.00$ & 1,210 & $\$ 2,420$ & 0 & $\$ 0$ & 0 & $\$ 0$ \\
\hline Irrigation supplies & acre & $\$ 1,200.00$ & 1 & $\$ 1,200$ & 1 & $\$ 600$ & 0.2 & $\$ 240$ \\
\hline Weed barrier/landscape fabric & linear foot & $\$ 0.28$ & 3,630 & $\$ 1,016$ & 0 & $\$ 0$ & 1,210 & $\$ 339$ \\
\hline Mulch & cubic yard & $\$ 20.00$ & 30 & $\$ 600$ & 0 & $\$ 0$ & 15 & $\$ 300$ \\
\hline Soil amendments \& fertilizer (organic) & acre & $\$ 1,200.00$ & 1 & $\$ 1,200$ & 1 & $\$ 1,200$ & 1 & $\$ 1,200$ \\
\hline Pest management materials (organic) & acre & $\$ 200.00$ & 1 & $\$ 200$ & 1 & $\$ 200$ & 1 & $\$ 200$ \\
\hline Cover/IPM/green manure crop seed & acre & $\$ 80.00$ & 1 & $\$ 80$ & 1 & $\$ 80$ & 1 & $\$ 80$ \\
\hline Equipment Operation & Unit & $\begin{array}{l}\text { Cost per } \\
\text { Unit }\end{array}$ & Quantity & Cost & Quantity & Cost & Quantity & Cost \\
\hline Electricity for well pump & kwh & $\$ 0.12$ & 747 & $\$ 90$ & 747 & $\$ 90$ & 747 & $\$ 90$ \\
\hline Fuel for tractor (2-wheel) & gallon & $\$ 2.50$ & 70 & $\$ 175$ & 40 & $\$ 100$ & 40 & $\$ 100$ \\
\hline Equipment repairs \& maintenance & acre & $\$ 150.00$ & 1 & $\$ 150$ & 1 & $\$ 150$ & 1 & $\$ 150$ \\
\hline Orchard Labor & Unit & $\begin{array}{c}\text { Cost per } \\
\text { Unit }\end{array}$ & Quantity & Cost & Quantity & Cost & Quantity & Cost \\
\hline Preparing planting rows, tilling & hour & $\$ 14.00$ & 20 & $\$ 280$ & 0 & $\$ 0$ & 0 & $\$ 0$ \\
\hline Laying mulch & hour & $\$ 14.00$ & 8 & $\$ 112$ & 0 & $\$ 0$ & 8 & $\$ 112$ \\
\hline Laying weed barrier & hour & $\$ 14.00$ & 4 & $\$ 56$ & 0 & $\$ 0$ & 0 & $\$ 0$ \\
\hline Planting \& replacing elderberry & hour & $\$ 14.00$ & 40 & $\$ 560$ & 10 & $\$ 140$ & 2 & $\$ 28$ \\
\hline Seeding cover crops & hour & $\$ 14.00$ & 8 & $\$ 112$ & 10 & $\$ 140$ & 10 & $\$ 140$ \\
\hline Irrigation management & hour & $\$ 14.00$ & 100 & $\$ 1,400$ & 80 & $\$ 1,120$ & 60 & $\$ 840$ \\
\hline Fertilizing \& amending soil & hour & $\$ 14.00$ & 50 & $\$ 700$ & 20 & $\$ 280$ & 20 & $\$ 280$ \\
\hline Mowing \& weed management & hour & $\$ 14.00$ & 80 & $\$ 1,120$ & 60 & $\$ 840$ & 60 & $\$ 840$ \\
\hline Scouting \& pest management & hour & $\$ 14.00$ & 30 & $\$ 420$ & 60 & $\$ 840$ & 60 & $\$ 840$ \\
\hline Pruning & hour & $\$ 14.00$ & 0 & $\$ 0$ & 0 & $\$ 0$ & 20 & $\$ 280$ \\
\hline Total & & & & $\$ 11,891$ & & $\$ 5,780$ & & $\$ 6,058$ \\
\hline
\end{tabular}


Table 3. Estimated yields, prices, harvest and postharvest costs, and revenues.

\begin{tabular}{|c|c|c|c|c|c|c|}
\hline Yield, Packout, Price, Revenue & Year 1 & Year 2 & Year 3 & Year 4 & Year 5 & Year 6 to 20 \\
\hline Gross berry yield per acre (pounds) & 0 & 250 & 1,000 & 2,500 & 4,000 & 4,500 \\
\hline \#1 berry packout percentage & $5 \%$ & $5 \%$ & $5 \%$ & $5 \%$ & $5 \%$ & $5 \%$ \\
\hline \#2 berry packout percentage & $95 \%$ & $95 \%$ & $95 \%$ & $95 \%$ & $95 \%$ & $95 \%$ \\
\hline \#1 berry average price $(\$ / \mathrm{lb})$ & $\$ 6.00$ & $\$ 6.00$ & $\$ 6.00$ & $\$ 6.00$ & $\$ 6.00$ & $\$ 6.00$ \\
\hline \#2 berry average price $(\$ / \mathrm{lb})$ & $\$ 3.00$ & $\$ 3.00$ & $\$ 3.00$ & $\$ 3.00$ & $\$ 3.00$ & $\$ 3.00$ \\
\hline Gross flower yield per acre (bunches) & 0 & 0 & 30 & 60 & 90 & 120 \\
\hline \#1 flower packout percentage & $100 \%$ & $100 \%$ & $100 \%$ & $100 \%$ & $100 \%$ & $100 \%$ \\
\hline \multicolumn{7}{|l|}{ \#2 flower packout percentage } \\
\hline$\# 1$ flower average price (\$/bunch) & $\$ 8.00$ & $\$ 8.00$ & $\$ 8.00$ & $\$ 8.00$ & $\$ 8.00$ & $\$ 8.00$ \\
\hline \multicolumn{7}{|l|}{$\# 2$ flower average price (\$/bunch) } \\
\hline Gross revenue per acre & $\$ 0$ & $\$ 788$ & $\$ 3,390$ & $\$ 8,355$ & $\$ 13,320$ & $\$ 15,135$ \\
\hline Variable Harvest \& Postharvest Costs & Year 1 & Year 2 & Year 3 & Year 4 & Year 5 & Year 6 to 20 \\
\hline Harvest labor hours & 0 & 8 & 36 & 89 & 142 & 162 \\
\hline Harvest labor rate (\$/hour) & $\$ 14.00$ & $\$ 14.00$ & $\$ 14.00$ & $\$ 14.00$ & $\$ 14.00$ & $\$ 14.00$ \\
\hline Harvest labor cost per acre & $\$ 0$ & $\$ 112$ & $\$ 504$ & $\$ 1,246$ & $\$ 1,988$ & $\$ 2,268$ \\
\hline Postharvest labor hours & 0 & 6 & 26 & 64 & 102 & 116 \\
\hline Postharvest labor rate $(\$ /$ hour $)$ & $\$ 14.00$ & $\$ 14.00$ & $\$ 14.00$ & $\$ 14.00$ & $\$ 14.00$ & $\$ 14.00$ \\
\hline Postharvest labor cost per acre & $\$ 0$ & $\$ 84$ & $\$ 364$ & $\$ 896$ & $\$ 1,428$ & $\$ 1,624$ \\
\hline Packaging/container cost per acre & $\$ 0$ & $\$ 50$ & $\$ 200$ & $\$ 500$ & $\$ 800$ & $\$ 900$ \\
\hline On-tree revenue & $\$ 0$ & $\$ 542$ & $\$ 2,322$ & $\$ 5,713$ & $\$ 9,104$ & $\$ 10,343$ \\
\hline
\end{tabular}

Table 4. Budget summary for a mature elderberry orchard.

\begin{tabular}{|c|c|}
\hline Revenues & Per Acre \\
\hline Gross revenue & $\$ 15,135$ \\
\hline Harvest \& postharvest cost & $\$ 4,792$ \\
\hline On-tree revenue & $\$ 10,343$ \\
\hline Orchard Operating Costs & Per Acre \\
\hline Materials & $\$ 2,359$ \\
\hline Equipment operation & $\$ 340$ \\
\hline Orchard labor & $\$ 3,360$ \\
\hline Fixed Production Costs & Per Acre \\
\hline Depreciation on fixed assets & $\$ 1,320$ \\
\hline Interest on fixed assets & $\$ 548$ \\
\hline Taxes \& insurance on fixed assets & $\$ 165$ \\
\hline Amortized costs from first 5 (pre-mature) years & $\$ 1,996$ \\
\hline Annual production margin per acre* & $\$ 255$ \\
\hline \multicolumn{2}{|c|}{$\begin{array}{l}\text { *Annual production margin is the return to selling-general-administrative (SGA) costs, land, and profit. SGA costs may include part of a } \\
\text { pickup truck expense, accounting services, office supplies, business registration fees, marketing costs, food safety compliance costs, organic } \\
\text { certification, and other general business costs. }\end{array}$} \\
\hline
\end{tabular}

